\title{
Affective Commitment to Organizations: A Comparative Study of Reverse Mentoring Versus Traditional Mentoring among Millennials
}

\author{
Catrin Hechl \\ School of Business and Technology, Northcentral University \\ 2488 Historic Decatur Rd, San Diego, CA 92106, United States \\ catrin.hechl@gmail.com
}

Received: $12^{\text {th }}$ June 2017/ Revised: $30^{\text {th }}$ July 2017/ Accepted: $31^{\text {st }}$ July 2017

How to Cite: Hechl, C. (2017). Affective Commitment to Organizations: A Comparative Study of Reverse Mentoring Versus Traditional Mentoring among Millennials. Binus Business Review, 8(2), 157-165.

http://dx.doi.org/10.21512/bbr.v8i2.3666

\begin{abstract}
This research addressed the high turnover rates among millennial employees. Specifically, it was unknown if millennials who received reverse mentoring had greater affective commitment to the organization than the millennials who had standard mentoring. Quasi-experimental design with two group post-test was conducted. A total of 90 participants (45 per group) completed the survey. The survey was conducted by Qualtrics, an online survey company. The sample population included male and female individuals, born between 1982 and 1998, employed by all types of organizations in the United States and participating in a mentoring program at the time the survey was taken. Affective commitment is greater in the reverse mentoring group $(\mathrm{M}=36,683, \mathrm{SE}=0,959)$ compared to the traditional mentoring group $(\mathrm{M}=34,984, \mathrm{SE}=0,959)$. However, after adjusting the quality of the relationship between Leader-Member Exchange (LMX) and Length and Frequency of Mentoring (LFM), there is no statistically significant difference $(p<0,05)$ between traditional mentoring and reverse mentoring on affective commitment to the organization indicated by $F(1,86)=1,569, p=0,214$.
\end{abstract}

Keywords: affective commitment, reverse mentoring, traditional mentoring, Leader-Member Exchange, millennials

\section{INTRODUCTION}

The current generation shifts in the workforce and its effect are an important topic for organizations. Nearly 150,6 million Americans participated in the labor force during the first quarter of 2015 (United States Census Bureau, 2015). There is a higher rate of turnover among employees of the millennial generation (Schwabel, 2013; United States Census Bureau, 2014). Moreover, the baby boomer generation retires at a pace of 10.000 per day (United States Census Bureau, 2015) and organizations struggle to retain millennials (Murphy, 2012, Schwabel, 2013). The need to mentor and develop millennials to counteract is higher than for normal (Cahill \& Sedrak, 2012).

The past literature focuses primarily on generational differences in an attempt to explain high turnover rates such as Cogin (2012), and Gursoy, Chi, and Karadag (2013). Practitioners and theorists agree that Leader Member Exchange (LMX) theory supports the idea that there are LMX relationships that may mitigate retention issues (Ahmed, Ismail, Amin, \& Ramzan, 2013). Traditional mentoring and reverse mentoring are both LMX relationships with a positive effect on the affective commitment to the organization. Then, many organizations have implemented mentoring programs to support their retention efforts (Murphy, 2012).

Every twenty years, a new generation arrives into the workforce. The managers also struggle to understand the new group of like-minded employees who are composed of similar ages and shaped by similar experiences. While a generational shift in the workforce is not a new phenomenon, the current 
generation shift is more impactful than the other generation shift in the past (Fry, 2015). For example, baby boomers retire at a rate of 10.000 per day (United States Census Bureau, 2015), and the generation that will soon be the largest cohort in the workforce is difficult to retain (Murphy, 2012; Schwabel, 2013). A study by the United States Census Bureau (2014) showed that millennials switched jobs after 12 to 18 months of being with an employer. This generation shift creates unique challenges for organizations.

The challenge can be the retirement age coupled with the challenge of retaining millennials for creative responses by organizations (Dye \& Lapter, 2013). Roodin and Mendelson (2013) identified the challenges and realities of having multiple generations in the workforce as a growing concern to all organizations. Identifying strengths of older workers and their younger counterparts, especially the millennial generation may represent a way to address the generation shift currently taking place. Ropes (2013) provided insight into the question whether intergenerational learning could be an option for organizations to address issues concerning the aging workforce population and the engagement, and productivity or not. It was found that intergenerational learning was an effective way to engage different generations in the workplace. Intergenerational learning also assured the knowledge transfer during the most recent generation shift.

Paying attention to the impact and consequences the most recent generation shift is also important to understand perceived differences of the various generations in the workforce to possibly mitigate some of the impacts. A significant number of research and academic papers and books have been written about this generation. Mostly focus on stereotypes about what makes this generation different from other generations. Kaifi, Nafei, Khanfar, and Kaifi (2012) reviewed existing researches on the topic regarding what constituted the core differences that had everyone discussed the millennial generation at length, especially in the workplace. They revealed some core traits and values assigned to the millennial generation. Core traits and values such as millennials were overachievers, but they were accountable for their actions. They also felt pressured to surpass their goals. Then, they were multitaskers, improvisers, team-oriented, and liked the flexibility, but disliked rules and regulations.

These differences of traits and values are often cited as the reason why organizations need to pay attention to this generation. It is also because they can greatly affect an organization's sustainability. The high turnover among members of the millennial generation appears to be one of the major workforces challenges today. There seems to be a different opinion among researchers about the causes and reasons of perceived generational differences. Many organizations face employee retention challenges that appear unusually extensive among employees of the millennial generation. The different opinions of researchers are outlined in Figure 1. It is whether the belief centers on generational differences or merely differences in age and experiences. The common denominator is the feeling of value, which affects engagement and retention, and imperative influencers in affective commitment to the organization.

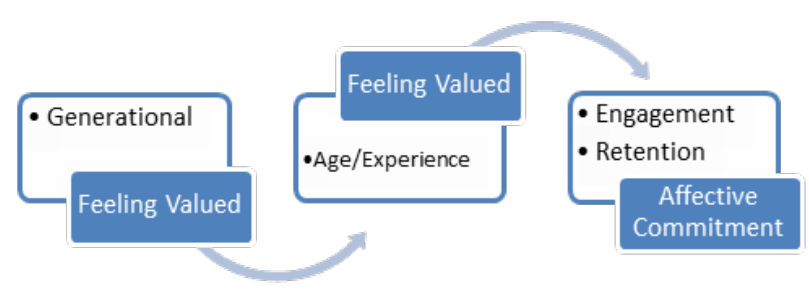

Figure 1 Affective Commitment Influencers

In recent years, the topic of employee retention has become a matter of interest for many leaders and human resource practitioners. It appears that employees change jobs quicker and more often than ever before, especially the millennial generation (Ertas, 2015). Researcher becomes interested in investigating what causes employees to leave organizations and producing results that leaders and practitioners can learn from and implement retention strategies through the findings.

The employee retention is important. Employees have always switched jobs, especially early in their careers. It is mainly for getting ahead a little faster monetarily and spending less time in advancing in their careers (Nolan, 2015). What happens in the last decade has changed the urgency of implementing retention strategies. The millennial generation has been identified as "job hoppers" (Ertas, 2015) not just at the beginning of their careers, but it appears throughout their careers (Nolan, 2015). Millennials change jobs every 12 to 18 months (United States Census Bureau, 2014). According to Nolan (2015), it is a high expense for employers. It shows that the cost to recruit and train employees can be as high as $50 \%$ of the employee's annual salary (Blatter, Muehlmann, \& Schenker, 2012) and at times as high as $250 \%$ (Nolan, 2015). A big component of effective retention is the affective commitment to the organization by employees (Meyer \& Allen, 1991).

Affective commitment is an employee's commitment to stay within the organization and indicates to what extent an employee identifies the organization and measures the engagement. The outcome of an affective commitment measure is an indicator whether the employee wants to stay with the organization or not. Gosh and Sayyawadi (2013) investigated which factors influenced an employee's intent to leave an organization the most. Findings showed that affective commitment was the best predictor of voluntary turnover. Affective commitment corresponded to an employee's attachment to the organization where the employee identifies an organizations' problems to be their own. Similarly, Aruna and Anitha (2015) conducted research 
to determine the prevailing factors influencing retention among employees who were the millennial generation. They revealed that mentoring support as a form of socialization emerged as the most important retention factor $(\mathrm{t}=2,01)$. Then, Craig, Allen, Reid, Riemenschneider, and Armstrong (2012) investigated the relationships between career mentoring and psychosocial mentoring with job involvement, and turnover intentions, which affective organizational commitment functioned as a mediator. They tested the hypotheses whether psychosocial mentoring or career mentoring would show a greater positive relationship with job involvement and turnover. Career mentoring focused on extrinsic success factors, while psychosocial mentoring focused on intrinsic functions such as role modeling and acceptance. The findings indicated a strong relationship between psychosocial mentoring and turnover intentions $(\beta=0,38, p<0,01)$. However, there was no relationship between career or psychosocial mentoring and job involvement. They also tested affective events theory by demonstrating that psychosocial mentoring influenced emotions triggering behavior about organizational commitment. The practical implication for leaders and managers needed to recognize the value and the positive effect of mentoring programs.

A theory that addresses relationship factors is LMX theory. Building and contribution to theory in management and organization often follows the postpositivist view of answering all questions related to definitions, domain, relationships, and predictive claims (Hamati-Ataya, 2012). The social-exchange theory represents the post-positivist view by providing information to test, develop, and contribute to the theory because of its heuristic nature (Bitektine \& Miller, 2015). They stated that mini-theories were more useful than broad theories led to the investigation and literature review on LMX theory. It represented a minitheory within social exchange theory. LMX theory evolved from differentiating leaders and subordinates within a work group, to a strictly relational concept where leader and follower were not the principal interest, but the relationship became the main focus (Graen \& Uhl-Bien, 1995). The LMX theory of the past was concerned about how leaders could influence followers by engaging only the best performers who were also referred as the in-group. Walumbwa, Cropanzano, and Goldman (2011) said that LMX theory was progressed to the current view of studying how LMX relationships affected all individuals' work values, self-perception, contribution, and feelings of being valued about organizational commitment and organizational outcome.

Numerous organizations employ mentoring as a tool to engage employees (Graen \& Schiemann, 2013). Then, Haggard (2012) investigated the importance of mentoring on social exchange relationships specifically the impact of a mentoring breach, and its effects on the mentee's intent to leave the organization. Haggard (2012) was the first to investigate a possible negative effect of mentoring relationships. The findings indicated that if mentoring was perceived as low quality, LMX was affected negatively, and consequently, job satisfaction was low and intent to leave the organization was high. LMX theory was applied to the dyadic interaction that a mentoring relationship created. This application of LMX theory did not accurately depict LMX theory and its application because mentoring would constitute a mediating construct. None of the LMX theory measures was used to find the impact of mentoring that might have on leader-member relationships. The researcher focused on social exchange theory and Psychological Contract Breach (PCB) and its effect on Perceived Organizational Support(POS). The practical implication centered around the need to provide training for mentors if mentoring programs were to be successful. Meanwhile, the researcher established a clear link to social exchange theory and psychological contract theory. There was no link to LMX theory, although the attempt was made by implying that mentoring was a form of leader-member exchange. A year after the research was published, Graen and Schiemann (2013) suggested adding mentoring to LMX theory in the future implying that there was a need to apply what scholars and practitioners learned over the span of 40 years since LMX theory was first introduced. It was about mentoring as a popular tool for many organizations, and it should have a place within LMX theory. Mentoring relationships were a common form of LMX in many organizations. However, not much was known how the perceived quality of mentoring affected a leader-follower relationship (Murphy, 2012).

The purpose of this quantitative research is to investigate whether millennials who receive reverse mentoring have greater affective commitment to the organization compared to millennials with standard mentoring. Both theory and practice help to solve the problem of millennial attrition.

\section{METHODS}

The research survey is designed as a general public survey with qualifying questions such as age and current participation in a mentoring program. It requires a minimum of 84 completed questionnaires of the millennial generation who is born between 1982 and 1998. They should also participate in the traditional mentoring program or a reverse mentoring program at the time of data collection. A link to the questionnaire is distributed by utilizing the online survey company, Qualtrics. The design of the research is a quasiexperimental design with two-group post-test. Then, LMX-7 as an instrument is to measure LMX quality as suggested by Graen and Uhl-Bien (1995). It is also to determine to what extent reverse mentoring or traditional mentoring influences the level of affective commitment in the organization. The turnover intent is measured by the participants' indication of their intent to leave the organization using validated questions 
from affective commitment survey by Meyer and Allen (1991). To determine possible factors that may have influenced respondents' answers, the researcher also asks about sociodemographic questions (age, level of education, employment status), and mentoring specific questions (the type of current mentoring, frequency, and length of current mentoring). Moreover, data analysis is performed through an Analysis of Covariance (ANCOVA). It determines whether the affective commitment is significantly different between traditional mentoring and reverse mentoring participants while controlling the length, frequency, and quality (LMX-7) of mentoring. The research investigates the hypothesis that millennials who receive reverse mentoring have greater affective commitment to the organization than millennials who receive standard mentoring.

Furthermore, the web-based survey includes several points. Those are three screening questions, informed consent, demographic questions, a question about participation in mentoring, time and length of interaction, and a combined survey consisting of eight questions from Meyer and Allen (1991), and seven questions from the LMX-7 questionnaire to measure the quality of mentoring relationship developed by Graen and Uhl-Bien (1995).

After completing the data collection, the survey data are downloaded for statistical analysis. The answer to the mentoring question separates the data into two groups. The groups are people who participate in traditional mentoring and those who take part in reverse mentoring. Data regarding quality of mentoring relationship, length and frequency of mentoring relationship, and affective commitment are summed up and divided by the number of answers of each appropriate subscale within the survey. ANCOVA is conducted to determine whether there is a statistically significant difference between traditional mentoring and reverse mentoring on affective commitment to the organization with quality of mentoring relationship, and length and frequency of mentoring relationship as control variables. Before data are analyzed, all statistical assumptions for ANCOVA are assessed and satisfied.

\section{RESULTS AND DISCUSSIONS}

The response rate for this research is $27,9 \%$. A total of 333 participants is invited to complete the survey. 299 participants consent. Out of that number, 93 participants complete the survey. The survey is conducted by procuring an email-list of potential participants from an online survey company, Qualtrics. An estimated 84 (42 per group) participants are required to attain $95 \%$ power with an effect size of 0,4 and a $p$ value of 0,05 , based on calculations by utilizing $G^{*}$ Power. Qualtrics stops the survey once the target responses are met. The total of 90 responses are valid (45 per group) and used in the analyses. Around 90 participants, 39 are male, and 51 are female. 10 participants are between the age of 18 and 23, 41 respondents are between the age of 24 and 29, and the remaining 39 respondents are between 30 and 34 years old. 24 respondents' length of employment at the time of the survey is between one and two years, while the majority of the respondents have been employed for two or more years at the time of the survey. Only six respondents have been employed less than a year at the time of the survey. 35 participants have earned bachelor degree, 18 are an associate degree, 15 have a master degree, and 4 have a terminal degree. Only 18 of all participants have a high school diploma as their highest attained level of education.

Based on the responses of each participant, the LMX-7 score is calculated by totaling the responses to the seven questions. On the Likert scale, points are assigned to each answer ranking from 1 to 6 . The guidelines established by Graen and Uhl-Bien (1995) are used to interpret the meaning of the scores. Those are very high (30-35), high (25-29), moderate (20-24), low (15-19), and very low (7-14). Scores in the upper ranges indicate stronger and higher quality exchanges, whereas scores in the lower ranges indicate exchanges of lesser quality. The majority of the respondents indicate that the relationship with their mentor or mentee is very high or high quality. There is no significant difference between the groups. The results are shown in Table 1 to Table 3.

Table 1 LMX-7 Scores (Groups Combined)

\begin{tabular}{clcc}
\hline & \multicolumn{1}{c}{ Answer } & Response & \% \\
\hline 1 & Score of 30-35 - very high & 39 & $43 \%$ \\
2 & Score of 25-29 - high & 36 & $40 \%$ \\
3 & Score of 20-24 - moderate & 12 & $13 \%$ \\
4 & Score of 15-19 - low & 3 & $3 \%$ \\
5 & Score of 7-14 - very low & 0 & $0 \%$ \\
\hline Note: $N=90$
\end{tabular}

Table 2 LMX-7 Scores (Traditional Mentoring Group)

\begin{tabular}{clcc}
\hline & \multicolumn{1}{c}{ Answer } & Response & \% \\
\hline 1 & Score of 30-35 - very high & 18 & $40 \%$ \\
2 & Score of 25-29 - high & 20 & $44 \%$ \\
3 & Score of 20-24 - moderate & 5 & $11 \%$ \\
4 & Score of 15-19 - low & 2 & $4 \%$ \\
5 & Score of 7-14 - very low & 0 & $0 \%$ \\
\hline
\end{tabular}

Note: $N=45$

Table 3 LMX-7 Scores (Reverse Mentoring Group)

\begin{tabular}{clcc}
\hline & \multicolumn{1}{c}{ Answer } & Response & $\mathbf{\%}$ \\
\hline 1 & Score of 30-35 - very high & 21 & $47 \%$ \\
2 & Score of 25-29 - high & 16 & $36 \%$ \\
3 & Score of 20-24 - moderate & 7 & $16 \%$ \\
4 & Score of 15-19 - low & 1 & $2 \%$ \\
5 & Score of 7-14 - very low & 0 & $0 \%$ \\
\hline Note: $N=45$
\end{tabular}


The length and frequency of mentoring are measured by asking participants to select one of the four options. The options are as follows a) less than six months, b) at least six months with a minimum of two interactions, c) six months to one year with at least four interactions, and d) one year or more with five or more interactions. For analyses purposes, the string answers are converted to numerical values with one represents less than six months, two as at least six months with a minimum of two interactions, three for six months to one year with at least four interactions, and four is one year or more with five or more interactions. Only a small group of participants has less than six months of mentoring. The majority participates in a mentoring relationship for a longer period. There are no significant differences between the two groups. The results are shown in Table 4 to Table 6.

Table 4 Length and Frequency of Mentoring (Groups Combined)

\begin{tabular}{llcc}
\hline \multicolumn{1}{c}{ Answer } & Response & \% \\
\hline 1 & $\begin{array}{l}\text { less than six months } \\
\text { at least six months with a mini- }\end{array}$ & 21 & $\begin{array}{l}11 \% \\
23 \%\end{array}$ \\
& $\begin{array}{l}\text { mum of one interaction } \\
\text { six months to one year with at } \\
\text { least four interactions } \\
\text { one year or more with five or } \\
\text { more interactions }\end{array}$ & 28 & $35 \%$ \\
\hline
\end{tabular}

Note: $N=90$

Table 5 Length and Frequency of Mentoring (Traditional Mentoring Group)

\begin{tabular}{llcc}
\hline \multicolumn{1}{c}{ Answer } & Response & \% \\
\hline 1 & less than six months & 5 & $11 \%$ \\
2 & $\begin{array}{l}\text { at least six months with a mini- } \\
\text { mum of one interaction } \\
\text { six months to one year with at }\end{array}$ & 10 & $22 \%$ \\
& $\begin{array}{l}\text { least four interactions } \\
\text { one year or more with five or } \\
\text { more interactions }\end{array}$ & 13 & $29 \%$ \\
\hline
\end{tabular}

Note: $N=45$

Table 6 Length and Frequency of Mentoring (Reverse Mentoring Group)

\begin{tabular}{llcc}
\hline \multicolumn{1}{c}{ Answer } & Response & \% \\
\hline 1 & $\begin{array}{l}\text { less than six months } \\
\text { at least six months with a mini- }\end{array}$ & 11 & $11 \%$ \\
mum of one interaction & $25 \%$ \\
3 & $\begin{array}{l}\text { six months to one year with at } \\
\text { least four interactions } \\
\text { one year or more with five or } \\
\text { more interactions }\end{array}$ & 14 & $31 \%$ \\
\hline Note: $N=45$
\end{tabular}

Based on participants' responses ranging from strong agreement to strong disagreement with eight questions from the Meyer and Allen (1991), it calculates each response with the 48 as the highest possible score and 8 as the lowest possible score. Four items on the commitment scale are strong agreement that reflects a lower level of commitment and are designed this way to encourage participants to think about each statement carefully. The results are shown in Table 7 to Table 9.

Table 7 Affective Commitment Scores (Groups Combined)

\begin{tabular}{llcc}
\hline \multicolumn{1}{c}{ Answer } & Response & \% \\
\hline 1 & $\begin{array}{l}40-48 \text { (very high level of com- } \\
\text { mitment) }\end{array}$ & 34 & $38 \%$ \\
2 & $\begin{array}{l}31-39 \text { (high level of commit- } \\
\text { ment) }\end{array}$ & 30 & $33 \%$ \\
3 & $\begin{array}{l}21-30 \text { (moderate to low level of } \\
\text { commitment) } \\
4\end{array}$ & 25 & $28 \%$ \\
& $\begin{array}{l}<20 \text { (very low level of commit- } \\
\text { ment) }\end{array}$ & 1 & $1 \%$ \\
\hline Note: $N=90$
\end{tabular}

Table 8 Affective Commitment Scores (Traditional Mentoring Group)

\begin{tabular}{clcc}
\hline \multicolumn{1}{c}{ Answer } & Response & \% \\
\hline 1 & $\begin{array}{l}40-48 \text { (very high level of com- } \\
\text { mitment) }\end{array}$ & 14 & $31 \%$ \\
2 & $\begin{array}{l}31-39 \text { (high level of commit- } \\
\text { ment) }\end{array}$ & 15 & $33 \%$ \\
3 & $\begin{array}{l}21-30 \text { (moderate to low level of } \\
\text { commitment) } \\
<20 \text { (very low level of commit- }\end{array}$ & 16 & $36 \%$ \\
\hline $\begin{array}{l}\text { ment) } \\
\text { Note: } N=90\end{array}$ & $0 \%$ \\
\hline
\end{tabular}

Table 9 Affective Commitment Scores (Reverse Mentoring Group)

\begin{tabular}{clcc}
\hline \multicolumn{1}{c}{ Answer } & Response & \% \\
\hline 1 & $\begin{array}{l}40-48 \text { (very high level of com- } \\
\text { mitment) }\end{array}$ & 20 & $44 \%$ \\
2 & $\begin{array}{l}31-39 \text { (high level of commit- } \\
\text { ment) }\end{array}$ & 15 & $33 \%$ \\
3 & $\begin{array}{l}21-30 \text { (moderate to low level of } \\
\text { commitment) } \\
\end{array}$ & 9 & $20 \%$ \\
& $\begin{array}{l}<20 \text { (very low level of commit- } \\
\text { ment) }\end{array}$ & 1 & $2 \%$ \\
\hline Note: $N=45$
\end{tabular}

A one-way ANCOVA is used to compare the traditional mentoring group to the reverse mentoring group, and to determine whether the different types of mentoring shows significant differences on affective commitment to the organization. LMX and length and LFM are the covariates to determine whether LMX and LFM will influence outcomes. It is believed that high perceived quality of interactions will affect the commitment level of mentor/mentee as well as the 
length and frequency ofmentoring. Alinear relationship exists between the covariates (LMX and LFM), and the dependent variable (affective commitment). For each level of the independent variable (reverse mentoring and traditional mentoring), It is confirmed by visual inspection of a scatter plot (Figure 2).

There was homogeneity of regression slopes $(p>0,05)$ as the interaction term is not statistically significant for $\mathrm{LMX}, \mathrm{F}(1,84)=0,066, \mathrm{p}=0,797$ and for LFM, $F(1,84)=3,266, p=0,074$. This can be seen in Table 10. Moreover, the standardized residuals for intervention are normally distributed in Table 11 as assessed by Shapiro-Wilk's test ( $p>0,05)$.

There is homoscedasticity of the standardized residuals plotted against the predicted values. The standardized residuals in the scatter plot are scattered randomly and with approximately constant spread as seen in Figure 3.

Based on Table 12, there is homogeneity of variances. It is assessed by Levene's test of homogeneity of variance $(p=0,868)$.

Adjusted means in Table 13 show that affective commitment is greater in the reverse mentoring group $(\mathrm{M}=36,683, \mathrm{SE}=0,959)$ than the traditional mentoring group $(\mathrm{M}=34,984, \mathrm{SE}=0,959)$. However, after adjusting the quality of relationship (LMX) and LFM, there is no statistically significant difference $(\mathrm{p}<0,05)$ between traditional mentoring and reverse mentoring on affective commitment to the organization indicated by $F(1,86)=1,569, p=0,214$. It is shown in Table 14 .
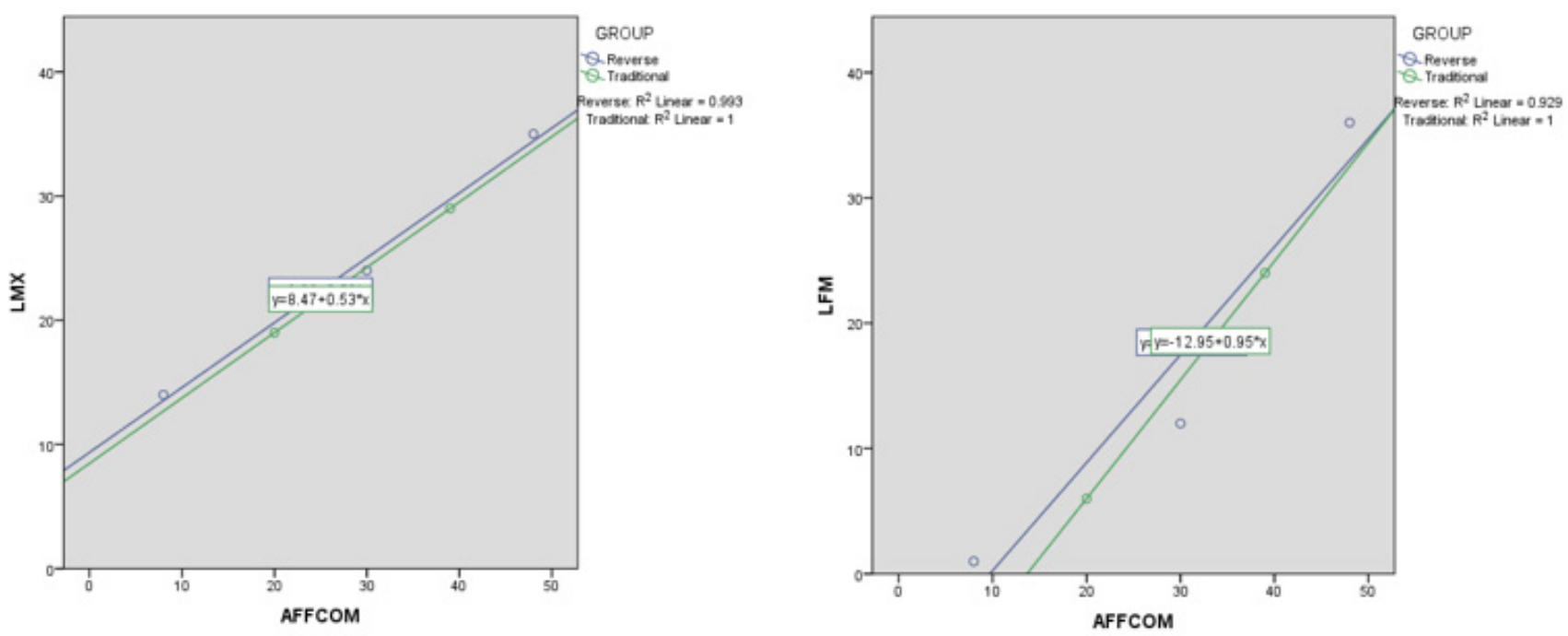

Figure 2 Linearity between LMX, LFM, and Affective Commitment

Table 10 Homogeneity of Regression Slopes

\begin{tabular}{lccccc}
\hline \multicolumn{1}{c}{ Source } & Type III Sum of Squares & df & Mean Square & F & Sig. \\
\hline Corrected Model & 977,187 & 5 & 195,437 & 4,796 & 0,001 \\
Intercept & 469,941 & 1 & 469,941 & 11,531 & 0,001 \\
Mentoring Group & 17,308 & 1 & 17,308 & 0,425 & 0,516 \\
LFM & 112,871 & 1 & 112,871 & 2,770 & 0,100 \\
LMX & 814,048 & 1 & 814,048 & 19,975 & 0,000 \\
Mentoring Group * LFM & 133,113 & 1 & 133,113 & 3,266 & 0,074 \\
Mentoring Group * LMX & 2,708 & 1 & 2,708 & 0,066 & 0,797 \\
Error & 3423,313 & 84 & 40,754 & & \\
Total & 119963,000 & 90 & & & \\
Corrected Total & 4400,500 & 89 & & & \\
\hline
\end{tabular}

Table 11 Shapiro-Wilk's Tests of Normality

\begin{tabular}{cccccccc}
\hline \multirow{2}{*}{ Type of mentoring } & \multicolumn{3}{c}{ Kolmogorov-Smirnov } & \multicolumn{3}{c}{ Shapiro-Wilk } \\
\cline { 3 - 7 } & & Statistic & df & Sig. & Statistic & df & Sig. \\
\hline Standardized Residual for & Traditional & 0,079 & 45 & $0,200^{*}$ & 0,983 & 45 & 0,727 \\
Affective Commitment & Reverse & 0,093 & 45 & $0,200^{*}$ & 0,972 & 45 & 0,336 \\
\hline
\end{tabular}




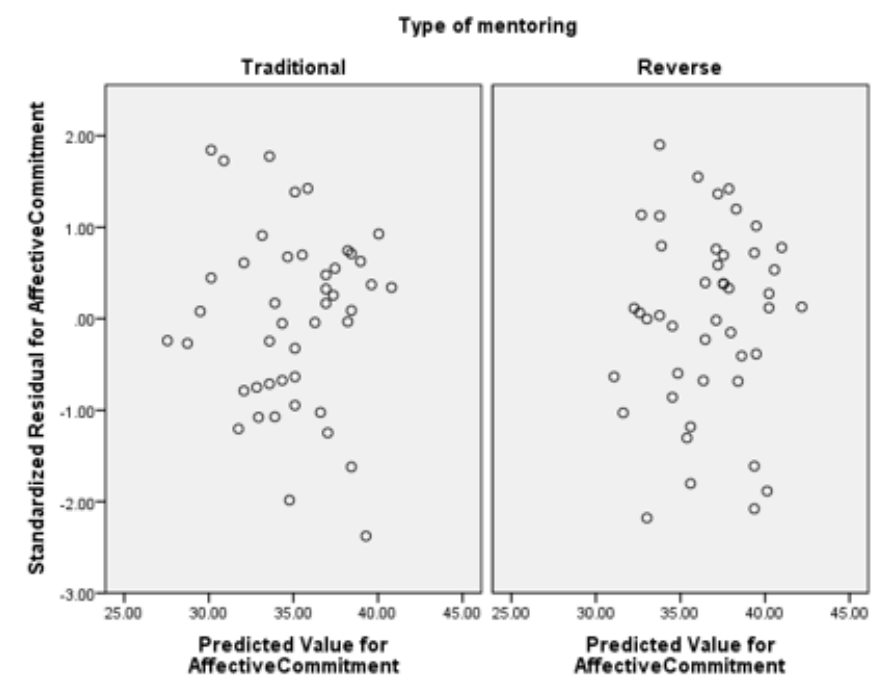

Figure 3 Homoscedasticity

Table 12 Levene's Test of Equality of Error Variances

\begin{tabular}{cccc}
\multicolumn{4}{c}{ Dependent Variable: } \\
\hline $\mathbf{F}$ & dffective & df2 & Sig. \\
\hline 0,028 & 1 & 88 & 0,868 \\
\hline
\end{tabular}

Table 13 Adjusted Means

\begin{tabular}{ccccc}
\hline & & & \multicolumn{2}{c}{ 95\% Confidence Interval } \\
\hline Group & Mean & Std. Error & Lower Bound & Upper Bound \\
\hline Traditional & $34,984 \mathrm{a}$ & 0,959 & 33,078 & 36,890 \\
Reverse & $36,683 \mathrm{a}$ & 0,959 & 34,776 & 38,589 \\
\hline
\end{tabular}

Table 14 Test of Between-Subjects Effects (ANCOVA)

Dependent Variable: Affective Commitment

\begin{tabular}{lcccccc}
\hline \multicolumn{1}{c}{ Source } & Type III Sum of Squares & df & Mean Square & F & Sig. & Partial Eta Squared \\
\hline Corrected Model & 842,173 & 3 & 280,724 & 6,785 & 0,000 & 0,191 \\
Intercept & 523,554 & 1 & 523,554 & 12,654 & 0,001 & 0,128 \\
LMX & 768,103 & 1 & 768,103 & 18,564 & 0,000 & 0,178 \\
LMF & 114,683 & 1 & 114,683 & 2,772 & 0,100 & 0,031 \\
Mentoring Group & 64,919 & 1 & 64,919 & 1,569 & 0,214 & 0,018 \\
Error & 3558,327 & 86 & 41,376 & & & \\
Total & 119963,000 & 90 & & & & \\
Corrected Total & 4400,500 & 89 & & & & \\
\hline
\end{tabular}

To evaluate the differences between reverse and traditional mentoring and affective commitment to the organization, two sub-groups are extracted from the overall data. The sub-groups are divided into the participants that have very high or high affective commitment score, and the participants who have moderate to low or very low affective commitment score. This is done to see whether there are significant differences between the means of LFM and LMX when affective commitment scores are high or low. Table 15 shows that LFM is very similar across all subgroups and does not indicate LFM to be a major influence as far as affective commitment is concerned. Relationship quality (LMX) is approximately the same in each subgroup as well. The higher the LMX score is, the higher the affective commitment score will be. Then, low affective commitment scores also show low LMX scores. It indicates that the quality of the relationship between mentee/mentor plays a significant role in affective commitment to the organization. A comparison of means among the three different age groups shows a linear relationship between LFM and LMX and affective commitment in Table 16. The older the participant is, the longer and 
more frequent the mentoring will be with the result of a higher relationship score and a high affective commitment score.

Table 15 Means of Affective Commitment (High/Low), LMF, and LMX

\begin{tabular}{lcccc}
\hline & $\begin{array}{c}\text { Traditional } \\
\text { Low Affec- } \\
\text { tive Com- } \\
\text { mitment }\end{array}$ & $\begin{array}{c}\text { Reverse } \\
\text { Low } \\
\text { Affective } \\
\text { Commit- } \\
\text { ment }\end{array}$ & $\begin{array}{c}\text { Traditional } \\
\text { High Affec- } \\
\text { tive Com- } \\
\text { mitment }\end{array}$ & $\begin{array}{c}\text { Reverse } \\
\text { High } \\
\text { Affective } \\
\text { Commit- } \\
\text { ment }\end{array}$ \\
\hline LFM & 2,77 & 3,08 & 2,95 & 2,64 \\
LMX & 27,19 & 27,7 & 30,68 & 29,55 \\
$\begin{array}{l}\text { Affective } \\
\text { Commitment }\end{array}$ & 30,08 & 30,78 & 41,79 & 42,77 \\
\hline
\end{tabular}

Note: $N=90 ; 41$ High Affective Commitment (22 Reverse, 19 Traditional); 49 Low Affective Commitment (23 Reverse, 26 Traditional)

Table 16 Means of Affective Commitment, LMF, and LMX by Age Group

\begin{tabular}{cccc}
\hline $\begin{array}{c}\text { Age } \\
\text { Group }\end{array}$ & LFM & LMX & Affective Commitment \\
\hline $18-23$ & 2,50 & 27,30 & 34,40 \\
$24-29$ & 2,83 & 28,66 & 35,17 \\
$30-34$ & 2,97 & 28,95 & 36,90 \\
\hline
\end{tabular}

Note: $N=90$

The results from the descriptive analyses indicate that the majority of the participants or $67 \%$ have been employed with the current employer for two years or more. This is significant in the problem of this research addressing the high turnover among millennial employees specifically findings by the United States Census Bureau (2014) that show that millennials switch jobs after 12-18 months of being with an employer. The research by the United States Census Bureau (2014) does not account for any mentoring interactions. The current findings corroborate previous findings by Craig et al. (2012), Payne and Huffman (2005), and Sun, Pan, and Chow (2014) whom all discover that mentoring intervention positively affects affective commitment in the organization. The findings show that there are no significant differences in analyzing and comparing high affective commitment scores and the length and frequency of mentoring between the two groups. However, there is a linear relationship between age of participant and LFM, LMX, and affective commitment. Then, the calculated means show older participants have longer and more frequent mentoring and higher scores on LMX and affective commitment.

The research addresses whether there is a significant difference between the group that receives traditional mentoring and the group that receives reverse mentoring concerning their affective commitment to the organization. The analyses are performed using a one-way ANCOVA. The adjusted mean shows a difference of affective commitment to the organization between the two groups. There is also no statistically significant difference between the two groups which confirm the null hypothesis. It can be concluded that mentoring overall affects the affective commitment to the organization, and there is no statistically significant difference between the two evaluated mentoring practices.

\section{CONCLUSIONS}

Overall, this research analyzes a relationship between mentoring and affective commitment to the organization. The research is a comparative study of two types of mentoring, traditional, and reverse. It also investigates whether there is a significant difference of affective commitment to the organization between the traditional mentoring group and the reverse mentoring group. It is the first study to evaluate the quantitative association of mentoring practices to the degree of affective organizational commitment among millennials. The previous research finds statistically significant differences in comparing employees who have traditional mentoring or reverse mentoring and employees with no mentoring at all. In addition, there is no statistically significant difference in affective commitment to the organization by comparing the traditional mentoring group to the reverse mentoring group.

Since the nature of the research is crosssectional and a snapshot at a specific time, the results may be different in another time frame. Hence, a time-lag longitudinal study will be beneficial. As this research is a comparison study between two different mentoring relationships involving participants across the United States in all types of organizations, future research should focus on one organization that practices reverse mentoring and examine the specific retention data in the organization.

\section{REFERENCES}

Ahmed, I., Ismail, W. K., Amin, S. M., \& Ramzan, M. (2013). Influence of relationship of POS, LMX and organizational commitment on turnover intentions. Organization Development Journal, 31(1), 55-68.

Aruna, M., \& Anitha, J. (2015). Employee retention enablers: Generation Y employees. SCMC Journal of Indian Management, 12(3), 94-103.

Bitektine, A., \& Miller, D. (2015). Methods, theories, data, and the social dynamics of organizational research. Journal of Management Inquiry, 24(2), 115-130. doi:10.1177/1056492614546897

Blatter, M., Muehlmann, S., \& Schenker, S. (2012). The costs of hiring skilled workers. European Economic Review, 56, 20-35. doi:10.1016/j. euroecorev.2011.08.001 
Cahill, T. F., \& Sedrak, M. (2012). Leading a multigenerational workforce: Strategies for attracting and retaining millennials. Frontiers of Health Services Management, 29(1), 3-15.

Cogin, J. (2012). Are generational differences in work values fact or fiction? Multi-country evidence and implications. The International Journal of Human Resource Management, 23(11), 2268-2294. doi:10. 1080/09585192.2011.610967

Craig, C. A., Allen, M. W., Reid, M. F., Riemenschneider, C. K., \& Armstrong, D. J. (2012). The impact of career mentoring and psychosocial mentoring on affective organizational commitment, job involvement, and turnover intention. Journal of Administration \& Society, 45(8), 949-973. doi:10.1177/0095399712451885

Dye, D., \& Lapter, A. (2013). The looming retirement and attrition wave: Are you prepared for the ride? Journal of Government Financial Management, 62(4), 26-32.

Ertas, N. (2015). Turnover intentions and work motivations of millennial employees in federal service. Public Personnel Management, 44(3), 401-423. doi:10.1177/0091026015588193

Fry, R. (2015). Millennials surpass Gen Xers as the largest generation in U.S. labor force. Retrieved from http://www.pewresearch.org/fact-tank/2015/05/11/ millennials-surpass-gen-xers-as-the-largestgeneration-in-u-s-labor-force/

Gosh, P., \& Sayyawadi, R. (2013). Who stays with you? Factors predicting employees' intention to stay. International Journal of Organizational Analysis, 21(3), 288-312. doi:10.1108/IJOA-Sep-2011-0511

Graen, G. B., \& Schiemann, W. A. (2013). Leadershipmotivated excellence theory: an extension of LMX. Journal of Managerial Psychology, 28(5), 452-469. doi:10.1108/JMP-11-2012-0351

Graen, G. B., \& Uhl-Bien, M. (1995). Relationship-based approach to leadership: Development of LeaderMember Exchange (LMX) theory of leadership over 25 years: Applying a multi-level multi-domain perspective. The Leadership Quarterly, 6(2), 219247. doi:10.101611048-9843(95)90036-5

Gursoy, D., Chi, C., \& Karadag, E. (2013). Generational differences in work values and attitudes among frontline and service contract employees. International Journal of Hospitality Management, 32, 40-48. doi:10.1016/j.ijhm.2012.04.002

Haggard, D. L. (2012). Mentoring and psychological contract breach. Journal of Business and Psychology, 27(2), 161-175. doi:10.1007/s10869-011-9237-2

Hamati-Ataya, I. (2012). Beyond (post) positivism: The missed promises of systemic pragmatism. International Studies Quarterly, 56(2), 291-305. doi:10.1111/j.1468-2478.2011.00710.x
Kaifi, B. A., Nafei, W. A., Khanfar, N. M., \& Kaifi, M. M. (2012). A multi-generational workforce: Managing and understanding millennials. International Journal of Business and Management, 7(24), 88-93. doi:10.5539/ijbm.v7n24p88

Meyer, J. P., \& Allen, N. J. (1991). A three-component conceptualization of organizational commitment. Human Resource Management Review, 1(1), 68-89. doi:10.10161/1053-4822(19)90011-Z

Murphy, W. M. (2012). Reverse mentoring at work: Fostering cross-generational learning and developing millennial leaders. Human Resource Management, 51(4), 549-574. doi:10.1002/hrm.21489

Nolan, L. S. (2015). The roar of the millennials: Retaining top talent in the workplace. Journal of Leadership, Accountability and Ethics, 12(5), 69-75.

Payne, S. C., \& Huffman, A. H. (2005). A longitudinal examination of the influence of mentoring on organizational commitment and turnover. Academy of Management Journal, 48(1), 158-168. doi:10.5465/ amj.2005.1599.3166

Roodin, P., \& Mendelson, M. (2013). Multiple generations at work: Current and future trends. Journal of Intergenerational Relationships, 11(3), 213-222. doi :10.1080/15350770.2013.810496

Ropes, D. (2013). Intergenerational learning in organizations. European Journal of Training and Development, 37(8), 713-727. doi:10.1108/EJTD11-2012-0081

Schwabel, D. (2013). The cost of millennial retention study. Retrieved from millennialbranding.com/2013/costmillennial-retention-study/

Sherman, J. D. (2002). Leader role inversion as a corollary to leader-member exchange. Group \& Organization Management, 27(2), 254-271. doi:10.1177/10501102027002005

Sun, L. Y., Pan, W., \& Chow, I. H. (2014). The role of supervisor political skill in mentoring: Dual motivational perspectives. Journal of Organizational Behavior, 35, 213-233. doi:10.1002/job.1865

United States Census Bureau. (2014). Employee tenure in 2014. Retrieved from www.bls.gov/news.release/ pdf/tenure.pdf

United States Census Bureau. (2015). Millennials outnumber baby boomers and are far more diverse. Retrieved from http://www.census.gov/newsroom/ press-releases/2015/cb15-113.html

Walumbwa, F. O., Cropanzano, R., \& Goldman, B. M. (2011). How leader-member exchange influences effective work behaviors: Social exchange and internal-external efficacy perspectives. Personnel Psychology, 64, 739-770. doi:10.1111/j.17446570.2011.01224.x 